\title{
CAPACITY BUILDING THROUGH GEOSPATIAL EDUCATION IN PLANNING AND SCHOOL CURRICULA
}

\author{
Pramod Kumar*, Asfa Siddiqui, Kshama Gupta, Sadhana Jain, Y.V.N. Krishna Murthy
}

Indian Institute of Remote Sensing, Dehradun-248001, India- (pramod, asfa, kshama, sadhana, director)@iirs.gov.in

\author{
Commission VI, WG VI/6
}

KEY WORDS: Geospatial technology, capacity building, Planning syllabi, 10+2 syllabi

\begin{abstract}
:
Geospatial technology has widespread usage in development planning and resource management. It offers pragmatic tools to help urban and regional planners to realize their goals. On the request of Ministry of Urban Development, Govt. of India, the Indian Institute of Remote Sensing (IIRS), Dehradun has taken an initiative to study the model syllabi of All India Council for Technical Education for planning curricula of Bachelor and Master (five disciplines) programmes. It is inferred that geospatial content across the semesters in various planning fields needs revision. It is also realized that students pursuing planning curricula are invariably exposed to spatial mapping tools but the popular digital drafting software have limitations on geospatial analysis of planning phenomena. Therefore, students need exposure on geospatial technologies to understand various real world phenomena. Inputs were given to seamlessly merge and incorporate geospatial components throughout the semesters wherever seems relevant. Another initiative by IIRS was taken to enhance the understanding and essence of space and geospatial technologies amongst the young minds at $10+2$ level. The content was proposed in a manner such that youngsters start realizing the innumerable contributions made by space and geospatial technologies in their day-to-day life. This effort both at school and college level would help in not only enhancing job opportunities for young generation but also utilizing the untapped human resource potential. In the era of smart cities, higher economic growth and aspirations for a better tomorrow, integration of Geospatial technologies with conventional wisdom can no longer be ignored.
\end{abstract}

\section{INTRODUCTION}

Education is the essence for a meaningful growth of a nation. It drives the entire mankind across the globe for an advanced outlook in difficult times. There has been tremendous growth in the area of imparting Geospatial science and education over the past few years, but the influence remains confined to certain countries. It is the urgent demand of the hour to emphasize on Geospatial education right from higher secondary school level and motivate the capacity building endeavours in India. The ambit of Geospatial education has been very well accepted in the world and sees no bounds. In spite of the technical nature of the subject, it has universal applicability in almost all walks of life. There is an urgent demand to conceptualize plausible curriculum status for seamless interaction between the real world scenarios with the content being taught. For this, Geospatial education has to be conceived as an essential component of the education system and should be incorporated in the syllabi of all branches of learning provided the curriculum is developed in a manner that the subject is understood clearly and well-received (Anon., 2013). This initiative will in true sense bring down the barriers on human imagination capability and give a shift to the conventional thought process.

The recent Urban and Regional Planning Development Formulation and Implementation (URDPFI) guidelines in India also envisage a concept of Smart Cities. To realize this concept, the education on Geospatial technology can play a major role.

\footnotetext{
* Corresponding author: pramod@iirs.gov.in
}

Keeping in mind the importance of disseminating knowledge in Geospatial technologies and applications, the Indian Institute of Remote Sensing (IIRS), on the request of Ministry of Urban Development (MoUD), Govt. of India (GoI), analysed the planning curricula and suggested recommendations on the prospects and approaches to integrate Geospatial technologies and applications in the teaching and learning curricula related to Planning. It is felt that with the ever-evolving technology in the Geospatial discipline and the growing demand for trained professionals, the content updation of the syllabi at graduate and post-graduate level is desirable to meet the demand created by this technological drift. This most needed change shall help in facilitating implementation and monitoring of the planning process in the long run as well as to realize the concept of Smart Cities in India. Similarly, it is also realized that Geospatial education can be imparted to the aspiring students at secondary and higher secondary level $(10+2)$. Hence, the inputs were provided for improvising Geospatial content at the school level also at the request of MoUD. This effort both at school and college level would help in not only enhancing job opportunities for young generation but also utilizing the untapped human resource potential.

\section{PROSPECTS OF GEOSPATIAL TECHNOLOGY IN PLANNING}

Cities are growing at a rate beyond imagination and Urban and Regional Planning (URP) helps in the management of resources shaping the cities of the future. Planning with the aim to integrate Geospatial content with the existing Planning syllabus 


\begin{tabular}{|c|c|}
\hline Semester & Suggestions \\
\hline 1 & $\begin{array}{l}\text { No changes/ additions required with respect to } \\
\text { Geospatial Techniques. }\end{array}$ \\
\hline 2 & $\begin{array}{l}\text { Surveying and Photogrammetry Lab: Adding } \\
\text { advanced surveying instruments as Unit } 6 \text { like } \\
\text { Aerial Light Detection and Ranging (LIDAR), } \\
\text { Terrestrial LiDAR, Ground Penetrating Radar } \\
\text { (GPR) and datum conversions. } \\
\text { Also, additions in unit } 5 \text { Photogrammetry e.g., } \\
\text { satellite remote sensing, Mobile mapping, Digital } \\
\text { Surface Model (DSM), Global Navigation } \\
\text { Satellite System (GNSS), and introduction to } \\
\text { Photogrammetric software }\end{array}$ \\
\hline 3 & $\begin{array}{l}\text { Changing the name of Computer Aided Drawing } \\
\text { Lab to "Introduction to Computer Aided Drawing } \\
\text { Lab and GIS". } \\
\text { Adding Unit } 5 \text { and } 6 \text { as Need for GIS and } \\
\text { Introduction to GIS (borrowed units from } \\
\text { Semester 6) } \\
\text { Units } 5 \text { and } 6 \text { talk about constraints in AutoCAD } \\
\text { working and use of Geographic Information } \\
\text { System (GIS) in URP Studies. Introduction to } \\
\text { open source software like QGIS, etc. }\end{array}$ \\
\hline 4 & $\begin{array}{l}\text { Introducing Geospatial Technologies for } \\
\text { Planning-I which includes Remote Sensing and } \\
\text { Image interpretation (borrowed from Semester 5) } \\
\text { and introducing Digital Image Processing (DIP) - } \\
\text { Image pre-processing, enhancement, fusion and } \\
\text { classification. } \\
\text { Use of GIS in Traffic and Transportation } \\
\text { planning, Environmental Impact Assessment } \\
\text { (EIA) using Geospatial Techniques }\end{array}$ \\
\hline 5 & $\begin{array}{l}\text { Renaming Geoinformatics for Planning to } \\
\text { Geospatial technologies for Planning-II. } \\
\text { Adding Unit } 6 \text { as Web GIS. } \\
\text { Adding BHUVAN- National Urban Information } \\
\text { System (NUIS), Meteorological and } \\
\text { Oceanographic Satellite Data Archival Centre } \\
\text { (MOSDAC), Street Map and other open source/ } \\
\text { distributed servers in Unit } 5\end{array}$ \\
\hline 6 & $\begin{array}{l}\text { In GIS Lab for Planning, introducing concepts } \\
\text { like spatial data modelling and decision support } \\
\text { system, multi-criteria decision modelling, Terrain } \\
\text { Analysis, etc. } \\
\text { Also introducing advanced topics like 3D } \\
\text { modelling and spatial sampling }\end{array}$ \\
\hline 7 & $\begin{array}{l}\text { Application of GIS and explanation through case } \\
\text { studies covering topics like Land Use and Land } \\
\text { Cover (LU/LC) map generation and change } \\
\text { detection, Municipal GIS, Infrastructure and } \\
\text { utility mapping, Urban Hazard mapping and Land } \\
\text { Subsidence Analysis, etc. } \\
\text { Introduction in subjects like Introduction to } \\
\text { Regional planning, Urban and rural governance } \\
\text { and Disaster risk Mitigation and Management }\end{array}$ \\
\hline 8 & $\begin{array}{l}\text { Thesis proposed to be completed using Geospatial } \\
\text { technologies with special emphasis on data sets } \\
\text { available in BHUVAN-NUIS and other Open } \\
\text { source/ distributed servers. }\end{array}$ \\
\hline
\end{tabular}

Table 1: Proposals at a Glance for B.Plan. Syllabus taught in Planning Institutes and Colleges, model All India Council of Technical Education (AICTE) syllabus (Anon., 2012) was studied in detail for Bachelor in Planning (B.Plan.) and Master in Planning (M.Plan) comprising of five disciplines on the request of MoUD.

\subsection{Bachelor in Planning (B.Plan.)}

Bachelor in Planning (B.Plan.) is offered in limited number of institutions in the country. The duration of the course is four years and eligibility criteria is Science subject with Mathematics background at intermediate level. It is considered to be the most crucial and important stage of education being imparted to youngsters in the field of planning. Hence, a need was felt to capture the potential of young generation and direct it right from the first year of their planning education. In this regard, the model AICTE syllabus was analysed thoroughly to be able to integrate Geospatial technology in the already existing syllabi and suggestions were given to improvise the contents (Table 1).

B.Plan. consists of four years and eight semesters. Semester 2, Semester 5 and 6 have already incorporated Geospatial technology as a part of Surveying and Photogrammetry Lab, Geo-informatics for Planning and GIS lab for Planning in the existing syllabi of model AICTE. A general observation after studying the curricula was made and following recommendations were given for improving the Geospatial contents:

- Geoinformatics is taught during $2^{\text {nd }}, 5^{\text {th }}$ and $6^{\text {th }}$ semesters of B.Plan. However, as the Geospatial Technologies are evolving continuously, its incorporation in other semesters is also relevant. It is suggested to use case studies and examples (wherever Geospatial data has utility) for better understanding of the subject and to learn the technology.

It was also felt that the conventional methods of digital drafting need to be replaced with the Geospatial technology enabled tools so as to increase the ability to analyse planning scenarios in Geospatial context. It is also suggested to use Geospatial Technologies in the Planning Studio Exercises for Site planning and City development Plan.

- Thesis is proposed to be completed using Geospatial techniques wherever spatial component is present. It is also advisable to make use of Geospatial technologies to support the planning, management and decision making.

\subsection{Master in Planning (M.Plan.)}

Master in Planning (M.Plan.) course is offered in many universities/ institutes in India including Indian Institute of Technology (IIT) and Schools of Planning and Architecture (SPAs). Planning is realized as a subject of importance for our growing cities and hence, this subject after graduation helps in managing development efficiently.

The eligibility criteria is multi-disciplinary and varies from institute to institute, however, in general, Architects, Planners, Civil Engineers, Geographers, Environmentalists, Economists and Sociologists are eligible to apply for the masters course. Other relaxations are also given in few colleges for eligibility. The four-semester course requires a thorough understanding of planning concepts and its specialized fields. M.Plan. has been further categorized into five planning disciplines viz., Urban Planning, Regional Planning, Environment Planning, Transport Planning and Housing as per the model AICTE syllabus. While 


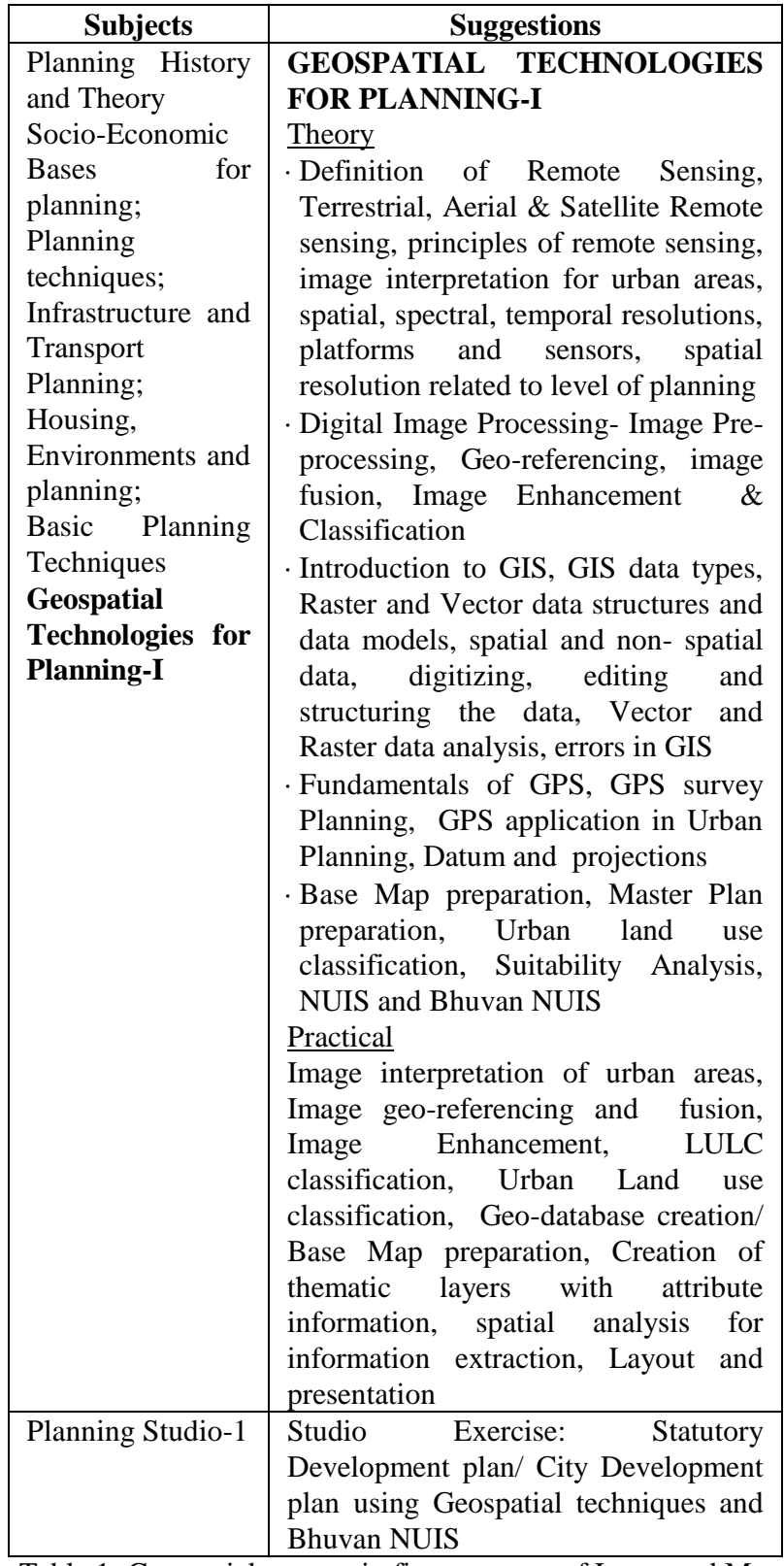

Table 1: Geospatial content in first semester of Integrated M. Planning course curricula (Proposal)

studying the syllabi content of all the five disciplines for all four semesters, it was found that Geospatial component is not evenly distributed in all semesters. It was also felt that Geospatial technology should be a part of all subjects wherever it finds relevance. It was also realized that since there are rapid advances in technology and new techniques have evolved in the field of Geospatial discipline e.g., Close Range Photogrammetry, LiDAR, GNSS, Terrestrial Laser Scanner (TLS), Web-GIS, etc., students shall attain the exposure at this level so as to face the competitive environment after completion of their education. Some of the general observations for all the specialized fields are as follows:

- Geospatial component shall be a part and parcel of the Studio Exercises in all semesters so that students are able to relate the live projects with the technology.

- Semester 1 is integrated semester for all disciplines. This semester gives an overview of all disciplines of Planning. It is advised to perform Studio exercise of making
Development Plan/ City Development Plan using Geospatial Techniques and Bhuvan NUIS (Table 2).

- To distribute the Geospatial course curricula evenly and for structured understanding of the subject in all the semesters, the syllabus was studied thoroughly. Accordingly, proposals (Table 3) were given to incorporate Geospatial technology in second semester as a separate subject in all the disciplines and incorporating the case studies in the course content wherever it has relevance.

- The end semester in all the disciplines is thesis semester. The students are required to work on a case study area on various planning issues prevalent in the country. During this semester, the students work individually unlike other exercises where work in a group is preferred. Hence, it is felt that thesis is the best time to utilize the GIS knowledge and present a Geospatial integrated Planning thesis. This approach is also advisable for better job prospects.

- Bhuvan-NUIS Portal has gained a lot of recognition after its launch. It should be used for preparation of base maps for starting the planning analysis further.

\begin{tabular}{|c|c|}
\hline \multicolumn{2}{|r|}{ Semester 2} \\
\hline Subject & Topic \\
\hline $\begin{array}{l}\text { Infrastructure } \\
\text { Planning }\end{array}$ & $\begin{array}{l}\text { Unit 5: Applications of Geospatial } \\
\text { Techniques for Infrastructure Planning } \\
\text { (including Geospatial Technology for } \\
\text { Infrastructure Planning, Water Supply } \\
\text { Network, Network Analysis, AM/FM, GIS } \\
\text { enabled Solid Waste Management (SWM), } \\
\text { Urban Transport Planning, Mobile mapping, } \\
\text { etc.) }\end{array}$ \\
\hline $\begin{array}{l}\text { Urban } \\
\text { Heritage } \\
\text { Conservation }\end{array}$ & $\begin{array}{l}\text { Unit 2: Heritage Conservation (Applications } \\
\text { of Terrestrial/ Close Range Photogrammetry/ } \\
\text { Terrestrial Laser Scanner) } \\
\text { Unit 4: Design in Human Habitation } \\
\text { (Geospatial Technology for Heritage Zone } \\
\text { mapping and preparation of conservation and } \\
\text { heritage management plans) }\end{array}$ \\
\hline $\begin{array}{l}\text { Advanced } \\
\text { Planning } \\
\text { Techniques }\end{array}$ & included in $1^{\text {st }}$ semester (integrated) syllabus \\
\hline $\begin{array}{l}\text { Geospatial } \\
\text { Technologies } \\
\text { for Planning- } \\
\text { II }\end{array}$ & $\begin{array}{l}\text { Theory } \\
\text { 1. Fundamental of Photogrammetry, } \\
\text { stereovision, measurement of } \\
\text { heights/depths by relief displacement and } \\
\text { parallax displacement, Digital Surface } \\
\text { Model, Digital Terrain Model, Interior } \\
\text { and exterior orientation, DSM generation, } \\
\text { Satellite Photogrammetry, Close Range/ } \\
\text { Terrestrial Photogrammetry } \\
\text { 2. Overview of LiDAR for Urban Surface } \\
\text { modelling, Terrestrial Laser Scanner, } \\
\text { Applications in Heritage and conservation } \\
\text { 3. Network analysis, Spatial Data modelling, } \\
\text { Overview of Open GIS, Overview of Web } \\
\text { GIS, OGC Geospatial Standards, } \\
\text { Geospatial/ WMS services, Location Based } \\
\text { Services, Introduction to Open source } \\
\text { distributed data servers such as Bhuvan } \\
\text { NUIS, India WRIS, MOSDAC, IBIN, BIS, } \\
\text { Earth Explorer etc. Field data collection } \\
\text { through Android based mobile phone } \\
\text { application, 3D GIS, Space Use Survey } \\
\text { 4. Ground Penetrating Radar (GPR) } \\
\text { fundamentals and applications, Mobile } \\
\text { mapping concepts and fundamentals for }\end{array}$ \\
\hline
\end{tabular}




\begin{tabular}{|c|c|}
\hline & $\begin{array}{l}\text { urban infrastructure planning and map } \\
\text { updation, Field data collection through } \\
\text { android based Mobile Phones } \\
\text { Practical } \\
\text { Preparation of base maps from topographical } \\
\text { sheets, orientation of stereo model, exercise } \\
\text { on map projection conversion, DSM and } \\
\text { ortho-image generation from stereo pair, } \\
\text { field exercise on GPS and DGPS survey, } \\
\text { field exercise on Mobile mapping for map } \\
\text { updation, 3D GIS, 3D Models generation } \\
\text { and visualization, Analysis in GIS (Buffer, } \\
\text { Proximity and Network), Hands-on on Web } \\
\text { GIS and WMS Services, Hands-on on open } \\
\text { source distributed Servers, Hands on Field } \\
\text { data collection through GPS enabled } \\
\text { Android based Mobile Phone, Hands-on on } \\
\text { Open GIS Systems }\end{array}$ \\
\hline & $\begin{array}{l}\text { Unit 1: included in 1st semester syllabus } \\
\text { Unit 2: Development plan using Geospatial } \\
\text { techniques }\end{array}$ \\
\hline \multicolumn{2}{|r|}{ Semester 3} \\
\hline \multicolumn{2}{|r|}{$\begin{array}{l}\text { Topic } \\
\end{array}$} \\
\hline $\begin{array}{l}\text { Urban } \\
\text { Development } \\
\text { and } \\
\text { Management }\end{array}$ & $\begin{array}{l}\text { Unit 4: Applications of Geospatial } \\
\text { Techniques for Urban Management } \\
\text { (Population estimation, identification of } \\
\text { squatter/unauthorized areas, Urban Sprawl } \\
\text { and Growth Modelling, Urban Utility } \\
\text { Mapping, SWM, Spatial Information } \\
\text { System, Tourism Information System, Multi } \\
\text { Criteria Decision Making, etc.) }\end{array}$ \\
\hline $\begin{array}{l}\text { Urban } \\
\text { Governance }\end{array}$ & $\begin{array}{l}\text { Unit 4: Institutions and Organizations } \\
\text { (Geospatial Techniques for property } \\
\text { taxation, Municipal GIS, land Information } \\
\text { System, Spatial data Infrastructure, } \\
\text { Participatory GIS) }\end{array}$ \\
\hline $\begin{array}{l}\text { Environment } \\
\text { Development } \\
\text { and Disaster } \\
\text { Management }\end{array}$ & $\begin{array}{l}\text { Unit 3: Geospatial technologies for Disaster } \\
\text { mitigation and Management (RS/GIS for } \\
\text { natural disasters, flood hazard zoning, } \\
\text { landslide hazard zonation, earthquake hazard } \\
\text { risk assessment, land subsidence study, } \\
\text { Thermal Analysis, etc.) }\end{array}$ \\
\hline $\begin{array}{l}\text { Energy, } \\
\text { Climate } \\
\text { change and } \\
\text { Urban } \\
\text { Development }\end{array}$ & $\begin{array}{l}\text { Unit 3: Energy Planning and Management, } \\
\text { and Mitigation and Adaptation to Climate } \\
\text { Change (Geospatial technology for analyzing } \\
\text { city form, energy efficient development, } \\
\text { solar potential utilization studies, wind flow } \\
\text { analysis, etc.) }\end{array}$ \\
\hline $\begin{array}{l}\text { Urban } \\
\text { Planning } \\
\text { Studio- II }\end{array}$ & $\begin{array}{l}\text { - Practical (Geoinformatics Lab: Population } \\
\text { estimation, Techniques of Space use } \\
\text { mapping, Network and Buffer Analysis, } \\
\text { Web GIS design, information System, } \\
\text { Geo-referencing cadastral maps and } \\
\text { delineation of peri-urban areas) } \\
\text { - Management and Governance Plans } \\
\text { exercises should be done in Geospatial } \\
\text { environment }\end{array}$ \\
\hline \multicolumn{2}{|r|}{ Semester 4} \\
\hline Sub & $\begin{array}{c}\text { Topic } \\
\end{array}$ \\
\hline Thesis & $\begin{array}{l}\text { Promote application of Geospatial } \\
\text { Techniques for Thesis wherever Spatial } \\
\text { component is involved }\end{array}$ \\
\hline
\end{tabular}

Table 2: Geospatial technology in three semesters of M. Planning with specialisation in urban planning (Proposal)
Similarly, the analysis and proposals were given for all the other four disciplines in great detail and wherever applicable the Geospatial component was added to the subjects.

\section{PROSPECTS OF GEOSPATIAL EDUCATION AT SCHOOL LEVEL}

Introduction of Geospatial technologies in Indian classrooms for teaching-learning purposes can create new avenues at a time when noteworthy efforts have been made by the Central and State Governments to formulate policies and introduce Information and Communication Technology (ICT) in schools. Several states in India have launched ICT as a compulsory subject in the secondary and higher secondary school curriculum. As a result, schools have been equipped with computer laboratories, internet connectivity and other related accessories. Teachers are encouraged to integrate ICT in the teaching-learning process, and in-service teacher training programs are offered to build computer and ICT-related skills and promote use of interactive software.

\begin{tabular}{|c|c|c|}
\hline Initiatives & Target & Content \\
\hline $\begin{array}{l}\text { Summer School for } \\
\text { School Children }\end{array}$ & $\begin{array}{l}\text { School } \\
\text { children from } \\
\text { Std. 9-12 }\end{array}$ & $\begin{array}{l}\text { Environmental } \\
\text { education through } \\
\text { data collection and } \\
\text { map making }\end{array}$ \\
\hline $\begin{array}{l}\text { Awareness } \\
\text { Workshops } \\
\text { Schools }\end{array}$ & $\begin{array}{l}\text { Govt./ Public } \\
\text { schools }\end{array}$ & $\begin{array}{l}\text { Simplified } \\
\text { overview } \\
\text { Geospatial } \\
\text { technologies }\end{array}$ \\
\hline $\begin{array}{l}\text { Science day/ Remote } \\
\text { Sensing Day/ GIS } \\
\text { day, etc. }\end{array}$ & $\begin{array}{l}\text { School } \\
\text { children from } \\
\text { Std. 9-12 } \\
\end{array}$ & Lectures, quiz, etc. \\
\hline $\begin{array}{lr}\text { Data } & \text { collection } \\
\text { through } & \text { Crowd- } \\
\text { sourcing } & \text { e.g., } \\
\text { MANU } & \end{array}$ & $\begin{array}{l}\text { College } \\
\text { students }\end{array}$ & $\begin{array}{lr}\text { Mobile } & \text { phone } \\
\text { based } & \text { data } \\
\text { collection } & \text { (GPS } \\
\text { coordinates, } & \\
\text { photographs) } & \\
\end{array}$ \\
\hline $\begin{array}{l}\text { NNRMS Teachers } \\
\text { Training programme }\end{array}$ & $\begin{array}{l}\text { College } \\
\text { teachers }\end{array}$ & $\begin{array}{l}\text { Multi-disciplinary } \\
\text { awareness } \\
\text { programmes }\end{array}$ \\
\hline \begin{tabular}{lr}
\multicolumn{2}{l}{ Collaborative } \\
programme & with \\
NCERT- & 3 \\
simultaneous & \\
workshops- & IIRS \\
(Northern & region), \\
NRSC & (Southern \\
region), & NATMO \\
(Eastern & region)- \\
2008 & \\
\end{tabular} & $\begin{array}{l}\text { Capacity } \\
\text { building for } \\
\text { teachers }\end{array}$ & $\begin{array}{l}\text { Multi-disciplinary } \\
\text { awareness } \\
\text { programmes }\end{array}$ \\
\hline $\begin{array}{lr}\text { E-learning } & \text { module } \\
\text { Generation } & \text { with } \\
\text { NCERT } & \\
\end{array}$ & $\begin{array}{l}\text { Govt./ Public } \\
\text { schools }\end{array}$ & $\begin{array}{l}\text { Multi-disciplinary } \\
\text { awareness } \\
\text { programmes }\end{array}$ \\
\hline
\end{tabular}

Table 3: Geospatial Education Initiatives at IIRS for School/ College Teachers and Students

Increasing accessibility of RS data and GIS software has made it easier for people to learn about Remote Sensing yet the training in Geospatial technologies has been lacking in educated faculty as well as students in most cases. In recent years, a number of educational institutes, both in government and private sector have come forward to organize degree courses, diploma and certificate courses in Geospatial technology. It is an encouraging trend but the training and 
educational facilities of this technology are still inadequate to meet the challenges of its growing demand and utility. There is an urgent need of diffusion of this technology to school and college level.

IIRS has taken many initiatives (Table 4) to enthuse the Geospatial concepts in young minds, where duration ranges from one-day workshop to 15 days workshops. IIRS has also contributed (Table 5) in preparing the Geospatial content for school children in recent past.

\begin{tabular}{|c|c|c|c|c|}
\hline Title & Series & Author(s) & $\begin{array}{l}\text { Publis } \\
\text { her }\end{array}$ & $\begin{array}{l}\text { Web } \\
\text { address }\end{array}$ \\
\hline $\begin{array}{l}\text { Remote } \\
\text { Sensing }\end{array}$ & $\begin{array}{l}\text { Reading to } \\
\text { learn series }\end{array}$ & $\begin{array}{l}\text { Minakshi } \\
\text { Kumar } \\
\text { (IIRS, } \\
\text { Dehradun) }\end{array}$ & $\begin{array}{l}\text { NCERT, } \\
2001\end{array}$ & $\begin{array}{l}\text { http://www.nc } \\
\text { ert.nic.in/publi } \\
\text { cation/ } \\
\text { children_book } \\
\text { s/books_pdf/ } \\
\text { catlogue(Eng). } \\
\text { pdf }\end{array}$ \\
\hline $\begin{array}{l}\text { Practical } \\
\text { Work } \\
\text { in Geogr } \\
\text { aphy-Part } \\
(1)\end{array}$ & \begin{tabular}{|l|} 
NCERT Book \\
for Class XI \\
(Introduction \\
To Remote \\
Sensing)
\end{tabular} & $\begin{array}{l}\text { Textbook } \\
\text { Development } \\
\text { Committee }\end{array}$ & NCERT & $\begin{array}{l}\text { http://upscport } \\
\text { al.com/civilser } \\
\text { vices/ncert- } \\
\text { books/class-xi- } \\
\text { practical- } \\
\text { work-in- } \\
\text { geography }\end{array}$ \\
\hline $\begin{array}{l}\text { Practical } \\
\text { Work } \\
\text { in Geogr } \\
\text { aphy-Part } \\
(2)\end{array}$ & $\begin{array}{l}\text { NCERT Book } \\
\text { for Class XII } \\
\text { (Spatial } \\
\text { Information } \\
\text { Technology) }\end{array}$ & & NCERT & $\begin{array}{l}\text { http://upscport } \\
\text { al.com/civilser } \\
\text { vices/ncert- } \\
\text { books/class-xi- } \\
\text { practical- } \\
\text { work-in- } \\
\text { geography }\end{array}$ \\
\hline
\end{tabular}

Table 4: NCERT Publications covering the Geospatial technologies at school level

\subsection{National Task force on Geospatial Education (MHRD)}

Realizing the importance of Geospatial education, MHRD, GoI constituted the National Task Force on Geospatial Education which discussed the overall issues related to Geospatial education in the country at school level, university level, training and outreach needs, need for high-end research and also the possibility of setting up of an institution for Geospatial education.

\subsubsection{Recommendation of Sub-committee for Geospatial Education at School Level}

The sub-committee in its report has mentioned that at present the Geospatial technology as a subject is offered at $10+2$ level either a part of geography curriculum or as an elective/ vocational/ additional subject (Anon., 2005). Major issues and concerns related to Geospatial technology are lack of trained faculty, spatial context, fundamental understanding to read a map, lack of amenities and infrastructure, etc. The important recommendations of the subcommittee are as under:

- The Geospatial elective should be offered at 10+2 level for all the students of arts/ science or commerce streams.

- Geospatial elective should focus on teaching advanced topics and applications and not the different GIS software.

- Schools should be equipped with Geospatial kits which will consist of basic course material on fundamentals and overview of Geospatial technologies, maps and satellite images, basic GPS devices, hard copy prints of the maps and "learning to think spatially" document.
- Advanced topic such as photogrammetry should be deferred to college level.

- Make learning of geography using Bhuvan/ Google Earth mandatory for all.

- Introduce GIS education (project based and interactive) as part of summer camps during summer vacations.

- Geospatial training to teachers should be imparted as to equip them to teach the subject.

- Besides 10+2 level, committee also recommended introducing Geospatial concepts as part of geography subject from Grade 3 onwards with the help of simple exercises such as Mapping the Neighbourhood, sketch map of one's own locality, preparing the road map and town map with important landmarks, visualization on Bhuvan/ Google earth, etc. From Grade 7 onwards, committee has recommended that students should be made familiarized with topo-sheets, satellite images of their own city, etc. Grade 9 and Grade 10 students are recommended to have knowledge of GIS, GPS and geodesy as part of geography/mathematics subject.

\subsection{Suggestions/ Recommendations}

Geospatial technology including Remote Sensing and Geographical Information System and other related techniques, have emerged as a powerful and imperative system in all disciplines of study along with research and planning in a short span of time. It covers satellite communication and satellite meteorology as well as satellite Remote Sensing. There is a great need to introduce the Geospatial technology in education system at various levels in a designed way to provide wider understanding and acceptance of this technology. Increasing accessibility of Remote Sensing data and software has made it easier for people to learn about Remote Sensing yet the training in Geospatial technologies has been lacking in educated faculty as well as students in most cases. In recent years, a number of educational institutes, both in government and private sector have come forward to organize degree courses, diploma and certificate courses in Geospatial technology. It is an encouraging trend but the training and educational facilities of this technology are still inadequate to meet the challenges of its growing demand and utility. There is an urgent need of diffusion of this technology to school and college level. The proposed syllabi for strengthening Geospatial contents in class XI and XII is listed in Appendix-1. Following are the few suggestions/recommendations related to Geospatial technology driven curriculum at school level:

- Space Technology and Societal benefits: The school children should be made aware of space technology and its various advantages for the societal benefits in general. The school children should be imparted knowledge on world space program and Indian space program in general and it's various applications in the fields such as communication, navigation, tele-education etc.

- Geospatial technologies for all: Geospatial technologies, satellite communication and navigation have become now a part of our daily routine lives. GPS enabled mobile devices, navigation maps imbibe in it Geospatial concepts, hence Geospatial technology should be introduced to all students irrespective of subject streams.

- Collaborative contents creation through crowd sourcing: Creating local database of a region and working along with children can be achieved through collaborative work and content creation by a team of disciplinary experts working with teachers and children. Recently, under the 'Map the 
Neighbourhood in Uttarakhand' (MANU) programme, an initiative of Department of Science \& Technology, aimed at collecting ground data through crowdsourcing about the damages in Uttarakhand during the year 2013, using a Mobile App developed by Indian Space Research Organization (ISRO). Using this, university students from the local area have successfully collected (after providing a short training) a lot of field data $(\sim 19,500$ points $)$ and uploaded to Bhuvan Geoportal." This App can be modified to educate the school children and collaborative projects can be launched to generate a database of school children's own local areas.

- Open Source GIS and Open source distributed data servers: Open Source GIS software can be harnessed for school students for introducing them the Geospatial concepts, map making and mapping the neighborhood exercises. Similarly, a large amount of remote sensing and allied data is made available online today through number of open source distributed servers such as Bhuvan, IBIN, WRIS, BIS, MOSDAC, earth explorer, etc. which can be used free of cost. Online data repositories available today provide data on topography, rainfall, temperature, vegetation, population, socio-economic details, etc. which can be directly linked to GIS platform and can be explored for the purpose in school classrooms.

- Establishing linkages between various stakeholders of school education: It is important to develop mechanisms, systems and procedures to bring together multiple stakeholders of education to a common forum to support school education.

\section{CONCLUSIONS}

The present study is an endeavour to study the existing model syllabi of AICTE for planning curricula at Bachelor and Master level and syllabi at $10+2$ level. It was realized that Geospatial contents is unevenly distributed across semesters in planning curricula at bachelor and master level. Therefore, few suggestions were made to seamlessly integrate the Geospatial contents in a structured manner in planning syllabi. At Bachelor level, the Geospatial content was spread throughout all the semesters with more emphasis on its incorporation in studio exercises. It was also suggested that theory subject teaching should be augmented with case studies and examples (wherever Geospatial data has utility) for better understanding of Geospatial technology and applications. Conventional digital drafting methods need to be replaced with GIS software so as to enhance the capabilities of planners to understand various real world phenomena. At M.Plan. level, the existing syllabi in the first integrated semester need to be improvised, henceforth, the detailed content of theory and practical were suggested. It is also advised to prepare Development Plan/ City Development Plan in this semester using Geospatial techniques and Bhuvan NUIS datasets. As the Geospatial technologies are evolving continuously, Geospatial technologies for planning-II were suggested as a separate subject across all five disciplines of $\mathrm{M}$. Planning that includes advanced topics such as Photogrammetry, LiDAR, GPR, GNSS, Web-GIS, etc. Detailed suggestions were also made in all the theory subjects of remaining three semesters across all the five disciplines at Master's level to incorporate Geospatial content wherever it has relevance in the form of case studies. It was also emphasized that students should be encouraged to use the Geospatial technologies in their studio exercises in place of conventional technologies. The final year project work is proposed to be completed using Geospatial techniques wherever spatial component is present at both Master and Bachelor level. It is also advisable to make use of Geospatial technologies and Bhuvan-NUIS to support the planning, management and decision making. This effort will enhance the understanding among planners for real world phenomenon and enable them to have a wider job avenues.

Detailed Geospatial content updation was also suggested at $10+2$ level of education. The content was proposed at school level in a manner such that youngsters start realizing the innumerable contributions made by space and geospatial technologies in their day-to-day life. This effort both at school and college level would help in not only enhancing job opportunities for young generation but also utilizing the untapped human resource potential. In the era of smart cities, higher economic growth and aspirations for a better tomorrow, integration of Geospatial technologies with conventional wisdom can no longer be ignored.

\section{ACKNOWLEDGEMENTS}

The authors acknowledge Dr. Sudhir Krishna, Ex-Secretary, MoUD, GoI for his inspiration to study the existing syllabi of Planning curricula and NCERT syllabus at 10+2 level. The authors are also thankful to Shri P.L.N. Raju, Group Head, Remote Sensing \& Geoinformatics Group, IIRS and Ms. Shefali Agarwal, Head, Photogrammetry \& Remote Sensing Department, IIRS for providing inputs on $10+2$ syllabi.

\section{REFERENCES}

Anon. 2005. Syllabus for Secondary and Higher Secondary levels, National Curriculum Framework, National Council of Educational Research and Training, http://www.ncert.nic.in/rightside/links/pdf/syllabus/vol2_hsl.zip

Anon., 2012. Model Curriculum for M. Plan/ M. Tech (Planning), 2012. All India Council for Technical Education, New Delhi. http://www.aicteindia.org/downloads/Master_planning_101212.pdf

Anon., 2013. Report of the National Task Force on Geospatial Education. Ministry of Human Resource Development, Government of India, New Delhi. http://mhrd.gov.in/reportnational-task-force-geospatial-education

Minakshi Kumar, 2001. Remote sensing. National Council of Educational Research and Training (India). http://www.ncert.nic.in/publication/ children_books/books_pdf/ catlogue(Eng).pdf

NCERT, 2007. Practical Work in Geography Part II, Textbook for Class XII. National Council of Educational Research and Training. http://upscportal.com/civilservices/ncert-books/classxi-practical-work-in-geography

\section{APPENDIX-I}

\section{Proposed Geospatial Technology Curriculum \\ Geospatial Technology (GT) Class XI \\ Total Marks 100 (Theory 60 + Practical 40)}




\section{Theory}

Chapter 1- Space Technology in Everyday Life [20 periods (10 marks)]

- Space Technology and Overview of World Space Program

- Overview of Indian Space Program

- Benefits of Space Program (Communication, Navigation, Entertainment, Tele-Education, Tele-Medicine, etc.)

- Natural Resource Management and Disaster Management

Chapter 2- Mapping \& Cartography [20 periods (10 marks)]

- What is Map and its Importance

- Different Types of Maps and Usage

- Elements of Map and Indexing

- Locating Yourself on Maps

Chapter 3- Remote Sensing [30 periods (20 marks)]

- Overview of Remote Sensing Technology

- Fundamentals of Remote Sensing

- Physics of Electro Magnetic Energy

Remote Sensing Platforms, Sensors and Data Products

- Satellite Images and Resolution

- Remote Sensing Applications

Chapter 4- Geospatial Overview [20 periods (10 marks)]

- Introduction to Geospatial Technology

- Why to Study Geospatial Technology

Importance of Geospatial Technology

Map Projections and Datum

- Mapping accuracies

- Interpretation of Satellite Images

Chapter 5- Sources of Remote Sensing Data [20 periods (10 marks)]

- Open Source Image Data Platforms- Bhuvan, Google Earth, Earth Explorer, etc.

- Locating your Neighbourhood on Satellite Images

\section{Geospatial Technology (GT) Class XII}

Total Marks 100 (Theory 60 + Practical 40)

Chapter 1- Fundamentals of GIS [20 periods (10 marks)]

- Geography in Spatial Context

- Fundamentals of GIS

- Components of GIS

- Data Types in GIS

- Application of GIS

Chapter 2- Basic Operations in GIS [30 periods (20 marks)]

- Spatial Analysis in GIS (Overlay and Buffer Operations)

- Creating Thematic Maps in GIS

- Creating a Map of your Neighbourhood and Town

- Creating information systems

- Mobile GIS and Field Data Collection

Chapter 3- Ground Positioning System [30 periods (20 marks)]
- Overview of GPS

- Functions of GPS

- Segments of GPS

- Accuracy of GPS

- Applications of GPS

Chapter 4- Space and Weather [20 periods (10 marks)]

- Weather, Climate, Climate Change

- Climatic/weather variables

Impact of Weather and Climate on our Lives

- Geospatial Technologies and Weather Monitoring

- Meteorological Data Servers- MOSDAC, etc.

\section{Practical}

Exercise - 1[3 periods (5 marks)]

- To map School building and surrounding environment

- Exercise - 2 [7 periods (5 marks)]

- To display the various types of thematic geological, political, meteorological and cadastral maps

- To read and identify Map features

- To learn usage of Maps

Exercise -3 [15 periods (10 marks)]

- To display two different scales of Topographical maps of same area

- To read Topographical maps index and identify the adjacent Topographical maps

- To understand the small and large scale concepts

- To compare the same area coverage by two different scaled Topographical maps

- To identify the different types of points line and polygon features

- To identify the map elements.

- To know the four coordinates of Topographical maps

To learn find out the location of any point.

Exercise -4 [15 periods (10 marks)]

- To display the satellite imagery and Topographical maps of same area

- To identify the same features from Topographical maps and Satellite image

- Compare the identified features with Topographical maps and satellite image

Exercise -5 [10 periods (5 marks)]

- To understand the GIS environment for example open file,

- Display images and operate various functions such as zoon in, Zoom out, open attribute table and reading them overlay etc.

Exercise -6 [10 periods ( 5 marks)]

- To Understand the GPS data collection and map them and prepare table of coordinates and elevation of all points collected.

- Compare the results using Bhuvan and Google maps. 